\title{
Does Food Assistance Improve Recipients' Dietary Diversity and Food Quality in Mozambique?
}

\section{Information about the authors:}

Author: Agatha Carol Zhou, Institute for Food, Nutrition and Well-being, University of Pretoria, Private Bag X20 Hatfield, 0028, South Africa

E-mail:acrzhou@gmail.com

Co-Author: Sheryl L Hendriks, Director Institute of Food \& Nutrition Wellbeing University of Pretoria, Private bag X20 Hatfield, 0028, South Africa

E-mail: sheryl.hendriks@up.ac.za

Corresponding author: Sheryl Hendriks, Director Institute of Food \& Nutrition Wellbeing University of Pretoria, Private bag X20 Hatfield, 0028, South Africa E-mail: sheryl.hendriks@up.ac.za

\section{ACKNOWLEDGEMENTS}

Fieldwork for this study was conducted by the World Food Programme in Mozambique and the Vulnerability and Analysis Group in Mozambique's Technical Secretariat for Food Security and Nutrition (SETSAN), Mozambique Ministry of Agriculture. The authors thank 
Zhou AC and Hendriks SL (2017). Does Food Assistance Improve Recipient's Dietary Diversity and Food Quality in Mozambique? Paper accepted by Agrekon, 56:3, 248-262. On line at http://www.tandfonline.com/doi/full/10.1080/03031853.2017.1360783.

the World Food Programme in Mozambique and SETSAN for permission to use the data analyzed for this study, the University of $\mathrm{X}$ for providing a postgraduate bursary and the National Research Foundation (NRF) (grant numbers CPR20110706000020, 77053 and 80529).

\begin{abstract}
Little is known about the potential for food assistance in the form of cash and food transfers to improve nutrition and create demand for nutritious food in crises. This study investigated the influence of the World Food Programme's cash and food transfers on the diversity and quality of diets among recipient households in Mozambique and the implications of this for the design of systemic food assistance intentions. The study found that direct food provision improved dietary diversity, while cash enabled beneficiaries to purchase more nutritious foods and improving their diet quality. Both cash and food transfers have potential to generate demand for a variety of nutritious foods in the communities investigated through this study. Providing adequate rations of basic food with a cash portion could improve both dietary diversity and quality and stimulate demand for nutritious foods by addressing both income (purchasing power) constraints as well as stimulating demand for these foods. This demand could have a pull factor in terms of local food systems, stimulating demand not only for food but also for food system services - both upstream and downstream provided a functioning market exists. Context analysis is necessary to understand if cash injections could lead to price spikes, eroding purchasing power and if the incentives exist for private traders to respond to demand.
\end{abstract}

\title{
KEYWORDS
}

Dietary diversity, Food Security, Mozambique, Nutrition, Food assistance 
Zhou AC and Hendriks SL (2017). Does Food Assistance Improve Recipient's Dietary Diversity and Food Quality in Mozambique? Paper accepted by Agrekon, 56:3, 248-262. On line at http://www.tandfonline.com/doi/full/10.1080/03031853.2017.1360783.

\section{INTRODUCTION}

Food assistance is provided in situations where the flaws, disruptions and breakages in the food system deprive individuals and households of essential nutrition and other basic needs (WFP 2017). Food assistance is a fundamental building block of humanitarian assistance, but is also an intervention to address vulnerability and food insecurity in development contexts. Recently, the World Food Programme (WFP) has recognised that its food assistance programmes have unparalleled capacity to address hunger and food insecurity in ways that support national efforts to achieve Sustainable Development Goal 2 (WFP 2017). Due to WFP's unique role at the intersection of commercial markets from which WFP sources food and food system services and the delivery of food assistance to beneficiaries, its programmes have the potential to drive changes in food systems to overcome these flaws, disruptions and breakages if engagements and investment are demand-driven, innovation-based and capacity-enhancing (WFP 2017).

While only six per cent of global food assistance programmes have adopted a cash transfer modality, many countries are developing national social protection systems that adopt a cash transfer modality (World Bank 2016). Forty countries in Africa now have unconditional cash transfer programmes (World Bank 2016). The share of humanitarian aid going to cash transfers was 5 - 6 per cent in 2014 (Overseas Development Institute (ODI) 2015). ODI (2015) report that if sectors where cash is often less appropriate (health, water and sanitation) and not appropriate at all (mine action, coordination, security) are removed, then cash and vouchers were roughly $10 \%$ of the total. The ratio of cash-based to in-kind transfers in 2016 was 19.16 to 24.86 respectively Lieberman 2017). The World Bank (2016), in a recent report (World Bank, 2016, page ix) prepared for the Inter-Agency Standing Committee for Humanitarian Assistance (IASC) explains that cash transfers can facilitate linkages between humanitarian and development programmes; but in-kind transfers will still be important strategic elements of humanitarian assistance in decades to come. The report recommends the development of a global research strategy to fill evidence gaps on the relative performance of transfer modalities, particularly beyond food security objectives.

In an effort to address this gap, this paper investigates the influence of WFP's cash and food transfers on the diversity and quality of diets in Mozambique and assesses the implications of 
Zhou AC and Hendriks SL (2017). Does Food Assistance Improve Recipient's Dietary Diversity and Food Quality in Mozambique? Paper accepted by Agrekon, 56:3, 248-262. On line at http://www.tandfonline.com/doi/full/10.1080/03031853.2017.1360783.

this for the design of WFP's systemic food assistance intentions. The findings contribute to understanding how WFP's current programmes affect household dietary diversity and quality. Such insight is essential to inform the design of future programmes as part of WFP's Strategic Plan for 2017 - 2021 (WFP 2016), but contributes more broadly to understanding the systemic food system influences cash and food transfers can have in development contexts.

\section{THE RELATIONSHIP OF FOOD ASSISTANCE AND FOOD SYSTEMS}

Food assistance empowers beneficiaries to access nutritious food, saving and protecting lives and livelihoods (WFP, 2017). It includes cash transfers, in-kind food transfers and vouchers, among other instruments. Efficient food systems should, among other attributes, provide adequate nutrition for households (HLPE, 2014). A food system comprises all the elements and activities that relate to the production, processing, distribution, preparation and consumption of food. Systemic food assistance seeks to improve food system performance by addressing systemic problems (those that affect groups as a whole rather than individually). These systemic problems include lack of purchasing power, lack of access to food markets and poor systems for food transportation etc. The WFP's (2017) new systemic food assistance approach seeks to leverage food assistance interventions for broad-based improvements in the food system that bring about general improvements way beyond direct beneficiaries. These wider benefits seek to improve overall sustainable food system performance, reducing poverty and hunger.

WFP uses both cash transfers and in-kind food transfers. The expression 'cash transfer' means cash given directly to individuals or households. Cash transfers are intended to meet people's basic needs (for both food and non-food items, and to buy assets and pay for services such as health and education) and to help them recover their livelihoods after a disaster (Herrmann 2009). 'Food transfers' provide food directly to individuals or households, so as to fill food consumption gaps directly (Stevenson and Gentilini 2008). However, the choice of instrument is context and sector-specific, requiring a case-by-case analysis. For this reason, WFP uses both cash and food transfers, informed by careful contextual analysis including beneficiary preference, gender concerns, safety and equality issues as well as needs and risks of specific vulnerable groups in each situation. 
Zhou AC and Hendriks SL (2017). Does Food Assistance Improve Recipient's Dietary Diversity and Food Quality in Mozambique? Paper accepted by Agrekon, 56:3, 248-262. On line at http://www.tandfonline.com/doi/full/10.1080/03031853.2017.1360783.

\section{SHIFTS IN FOOD ASSISTANCE APPROACHES}

Until the global food price crisis of 2007/8, shipping of food aid from abroad to needy countries was a standard humanitarian response (Maxwell, Lentz and Barrett 2007). The 2007/8 crisis saw the lowest grain stock levels in more than two decades and high commodity and fuel prices, making it very expensive to transport goods. A global recession followed the crisis. Humanitarian agencies faced growing demand for food aid but donor countries simply did not have the stocks or funds to ship food aid abroad (Jones, Vavra, von Lampe, et al. 2010). Even before the global food price crisis, the international humanitarian aid community was considering alternative responses such as social protection (Gentilini 2014; HLPE 2012). These deliberations focused on better targeting, local procurement and the use of ICTs to make cash transfers via mobile phones, vouchers and smartcards (Omamo, Gentilini and Sandstrom 2010).

The demand for alternative welfare systems to alleviate suffering and food insecurity in food emergency and non-emergency situations has grown as traditional informal social transfers decline (HLPE 2012; Oduro 2010). Informal social assistance is not always reliable and predictable as family members may not always be in a position to help their relatives (Oduro 2010). Kinship and community assistance systems have long been important in traditional societies for providing relief from shocks and crises and filling temporary food consumption gaps (Oduro 2010), referred to as the `bad year` or `lean season` systemic problem (WFP 2017). However, these community assistance systems have been eroded by global influences such as unfavourable exchange rates, conflict, diseases such as HIV, recurring natural disasters, persistent rural poverty and outmigration (Barrientos 2010; Coady 2004).

Over the past decade, changing global and local contexts have raised awareness of the need for more efficient and large-scale rollouts of social transfers (HLPE 2012). Literature documents the benefits and advantages of cash and food transfers, outlining their advantages and disadvantages (HLPE 2012). Proponents of cash transfers argue that these are less stigmatized than food transfers are - the handing over of food parcels is visible to all observers (Grosh et al. 2008). Cash transfers allow beneficiaries to choose their purchases (Farrington and Slater 2006), whereas providers decide the content of food parcels (Stevenson and Gentilini 2008). Proponents of food transfers argue that these overcome the problem of beneficiary inclusion errors: only 
those who are really in need will collect these parcels because of the stigma attached (Currie and Gahvari 2008; Drèze 1990). Food transfers may be more appropriate where the consumption of certain foods - such as fortified foods - is encouraged (Currie and Gahvari 2008). Cash transfers give beneficiaries the choice of what to buy, but cash transfers may not necessarily lead to sound nutritional choices (FAO 2002; Gentilini 2007). Indeed, there is little control over what beneficiaries purchase with the cash. They may indeed use it for procuring other essential nonfood household requirements such as health services, schooling or agricultural inputs. The lack of control over the usage of cash transfers may be the reason why some donors are reluctant to disburse cash and prefer instead to give food transfers (Audsley, Halme and Balzer 2010; Harvey 2007).

However, Harvey and Bailey (2011) note that among the issues humanitarian agencies take into account when deciding which method to adopt are:

- $\quad$ Can beneficiaries buy what they need at stable and appropriate prices in local markets?

- $\quad$ Can the cash be safely delivered and spent?

- Will food distribution be more cost effective than transferring cash?

Very little research has been conducted on the nutrition-related benefits of these modalities (World Bank 2016). Such assessments are essential for clear, evidence-based guidance for different contexts and different target groups (Arnold, Conway and Greenslade 2011), and in determining the impact of these interventions on food systems.

\section{EVIDENCE OF THE INFLUENCE OF TRANSFERS ON NUTRITION}

While cash transfers are among the most rigorously evaluated fields in social sciences, the recent World Bank (2016) report to the IASC indicates that there is a gap in knowledge and evidence related to where and when cash transfers are better relative to other transfer modalities. Most existing evidence comparing transfer modalities is drawn from non-emergency contexts. In addition, a significant knowledge gap exists with regard to the influence of cash transfers on nutrition. Likewise, there has been very little research on the impact of in-kind transfers on local markets (World Bank, 2016). This section of the paper reviews available evidence of the influence of cash and food transfers on diets and diet quality. 
Zhou AC and Hendriks SL (2017). Does Food Assistance Improve Recipient's Dietary Diversity and Food Quality in Mozambique? Paper accepted by Agrekon, 56:3, 248-262. On line at http://www.tandfonline.com/doi/full/10.1080/03031853.2017.1360783.

Hoddinott and Wiesmann (2010), found that cash transfers resulted in an increase in energy intake of 5.6 per cent in extremely poor households as a result of the PROGRESSA (Programa de Educación, Salud, y Alimenación) in Mexico, a 6.9 per cent increase as a result of the PRAF (Programa de Asignación Familiar) Family Allowance Program in Honduras and a 12.7 per cent increase as a result of the RPS (Red de Protección Social) Network of Social Protection in Nicaragua. In all three cases, micronutrient intake and dietary diversity also increased. These findings have been confirmed by Hoddinott and Skoufias (2004), Caldes, Coady and Maluccio (2006), Molyneux (2007), Fiszbein, Schady, Ferreira et al. (2009) and de Brauw and Hoddinott (2011) in Mexico; Latin America; Brazil; Africa, Asia, South America, Latin America, the Carribean and Mexico respectively.

Rabbani, Prakash and Sulaiman (2006) found that beneficiary households spent more cash on food and consumed more foods from animal sources, significantly improving consumption quantity and quality among selected ultra-poor households benefiting from cash and food transfers in the Bangladesh Rural Advancement Committee (BRAC) program. Rabbani et al. (2006) and Matin, Sulaiman and Rabbani (2008) have confirmed these findings in other studies in Bangladesh.

Far fewer studies have been conducted on the impact of social protection on food insecurity in Africa, with the exception of Ethiopia (Arnold et al. 2011). Gilligan, Hoddinott and Taffesse (2008) and Andersson and Mekonnen (2011) have evaluated the impact of Ethiopia's Productive Safety Net Program (PSNP) cash transfers. Gilligan et al. (2008) found that, the mean calorie intake increased among households participating in the PSNP compared to the control group. Andersson and Mekonnen (2011) also found that the PSNP increased the long-term income earning potential of households. Audsley et al. (2010) assessed cash and food transfers in Malawi's Improving Livelihood through Public Works Program (ILTPWP) and found that food consumption and dietary diversity improved the most for the cash-recipient and least for the food-recipient beneficiaries. Devereux's (2010) assessment of South Africa's cash transfer program provides evidence that the Child Support Grant reduced child hunger more in households receiving the grants than in households that did not. 
Zhou AC and Hendriks SL (2017). Does Food Assistance Improve Recipient's Dietary Diversity and Food Quality in Mozambique? Paper accepted by Agrekon, 56:3, 248-262. On line at http://www.tandfonline.com/doi/full/10.1080/03031853.2017.1360783.

Intervention programs must be context specific and are not necessarily directly replicable (Gough and Wood 2004). Designing an appropriate food security intervention strategy requires an understanding of what will work best work for a specific context. Evidence from Ecuador, Uganda, Niger and Yemen show that the relative effectiveness of the two methods, cash or food, depended on contextual factors such as the severity of food insecurity and the robustness of markets for grains and other foods (Hoddinott, Gilligan Hidrobo et al. 2013; (Hidrobo et al. 2014).

Studies in developing countries have confirmed the positive relationship between dietary diversity and nutrient intakes (Ruel 2002). In the past, programs were designed to ensure sufficient energy intake. Now they are increasingly being designed to improve dietary diversity and quality so as to remedy micronutrient deficiencies. Such improvements are especially relevant in developing countries where diets are typically starch-based and low in micronutrient content, the consumption of animal proteins is low, and consumption of fruit and vegetables is low or seasonal (Ruel 2002). Inadequate dietary intake leads to poor health and reduced productivity, perpetuating poverty and hunger from generation to generation (FAO 2002; Victora, Adair, Fall et al. 2008; Wagstaff and Watanabe 2000).

It is well documented in the development literature that as household income increases, diets consisting largely of bland staple foods such as cereals, roots and tubers begin to include more micronutrient rich foods such as meat, fish, dairy products and, to a lesser extent, fruit and vegetables (Heady and Ecker 2013). Humanitarian aid and food security programs have begun to focus on improving nutrition to break the cycle of poverty and hunger, especially for mothers and young children (Barrientos 2010). However, we do not know whether cash and food transfers have similar effects on food consumption patterns in crises.

\section{STUDY CONTEXT}

Mozambique was considered the poorest country in the world since 1992 (Arndt et al. 2012), and remained one of the poorest countries in world, ranking number 185 out of 187 countries in the 2015 Human Development Report (Jahan 2015). In urban areas, the major constraint to food security is income, especially in times of high food prices (Fidalgo 2011). In rural areas, where 
Zhou AC and Hendriks SL (2017). Does Food Assistance Improve Recipient's Dietary Diversity and Food Quality in Mozambique? Paper accepted by Agrekon, 56:3, 248-262. On line at http://www.tandfonline.com/doi/full/10.1080/03031853.2017.1360783.

the majority of the Mozambican population lives, income constraints and physical access are major constraints to food security. Physical access to food in the rural areas is constrained by poor roads and markets infrastructure, both of which were destroyed during the Mozambican civil war (Fidalgo 2011).

Despite good economic growth after the civil war, a large proportion of Mozambique's population continue to experience food insecurity (WFP/TSFSN/GAV 2010). At the time of the current study, the most recent Comprehensive Food Security and Vulnerability Analysis data (2009) showed that $34 \%$ of households continued to face chronic food insecurity while $25 \%$ of the households faced acute food insecurity (WFP/TSFSN/GAV 2010). This analysis was done by applying WFP corporate indicators of food access, where households were classified into food secure, acutely food insecure and chronically food insecure based on a food consumption score, an asset score and the coping strategies index (WFP/TSFSN/GAV 2010). Food insecurity levels in Mozambique vary geographically, depending on the levels of poverty, agro-ecology of specific areas as well as exposure and vulnerability to shocks such as droughts, floods and cyclones (USAID 2007).

The situation presents what is termed the typical 'bad year' or 'lean season' problem where communities affected by natural hazards, armed conflict, civil strife and economic shocks that overwhelm their abilities to cope (WFP, 2017). The problem exists when large numbers of households with low incomes, poor purchasing power and few assets face severely constrained access to nutritious food. These communities often face periods of constrained access to food that lead to extreme hunger - termed the 'lean season' (WFP, 2017). The percentage of people living below the international poverty line was 54.7\% in 2013 (Malik 2013). For this reason, WFP has implemented cash and food-for-work programs in Mozambique to support chronically hungry households. Agricultural production in Mozambique is usually low between October and March. As most poor households depend on agriculture for food, food insecurity is especially high during this lean season (WFP 2011). The cash and food transfers were timed to fall within the lean months and run for six months per household. This paper reports the findings of a study that evaluated the dietary impact of the program against a counterfactual group. 
Zhou AC and Hendriks SL (2017). Does Food Assistance Improve Recipient's Dietary Diversity and Food Quality in Mozambique? Paper accepted by Agrekon, 56:3, 248-262. On line at http://www.tandfonline.com/doi/full/10.1080/03031853.2017.1360783.

Community-based targeting was used to select the cash and food transfer beneficiaries. The process relied on local information, standards and circumstances and took into account local interpretation of food insecurity and an inadequate standard of well-being. Community leaders and members to used socio-economic criteria to identify the transfer recipients. These criteria included poverty-related characteristics such as household demographics (size of household and ages of the household members), human capital (enrolment of children in school), housing (for example type of roof or floor), ownership of durable goods, ownership of productive assets (such as land or animals), levels of income and food security, and nutrition indicators (number and frequency of meals). Selected beneficiaries were expected to engage in public works programs. This, together with the fairly low wage offered, i.e. US\$20, or the food equivalent of 45 kilograms of cereal, nine kilograms of cowpeas and three-quarters of a litre of oil per month, encourages self-selection as only those in real need would accept these conditions.

\section{METHODOLOGY}

The study included three groups of respondents: beneficiaries of the WFP Mozambique cash-forwork program, beneficiaries of the WFP Mozambique food-for-work program and a counterfactual group of non-beneficiaries drawn from a national sample. Data for this study was not obtained from an experiment, but from secondary data sourced from an Outcome Monitoring Survey carried out by WFP and a National Food Security survey conducted by the Mozambique Government.

Data for the cash and food transfer beneficiaries were obtained from the WFP Mozambique Outcome Monitoring Survey. The WFP Outcome Monitoring Survey was carried out in January 2013 ( $n=456)$. The survey was conducted in areas where WFP cash- and food-for-work programs had been implemented in 14 Mozambique districts in six of the 10 provinces between October 2011 and December 2012. Food insecure households received food rations at food distribution centres or monthly cash transfers into individually held bank accounts in return for participating in public work schemes organised by the local government authorities. Cash transfers were withdrawn monthly by the households at the nearest bank branch, using automatic teller machines (ATM) cards. The food for work or food for cash activities were of a disaster- 
Zhou AC and Hendriks SL (2017). Does Food Assistance Improve Recipient's Dietary Diversity and Food Quality in Mozambique? Paper accepted by Agrekon, 56:3, 248-262. On line at http://www.tandfonline.com/doi/full/10.1080/03031853.2017.1360783.

mitigating nature such as digging small water reservoirs, building drainage systems, growing tree seedling nurseries or planting trees for wind breaks. Districts and localities were assigned to cash or food transfers based on WFP`s available resources for cash or food distributions. A prerequisite for cash transfers was the availability of banking services in the district or locality. WFP Mozambique periodically undertakes biannual outcome monitoring surveys, in January and in June, covering areas in which WFP has intervention programs. The outcome monitoring survey is periodically carried out by a team of evaluators who go out into the field to collect data for the monitoring and evaluation.

The WFP Mozambique Outcome Monitoring Survey was undertaken in localities where the WFP had distributed cash and food transfers in the previous 30 days to generate the sample data. Households were the primary sampling unit for the quantitative evaluation. The respondent was the household head or the head's spouse. Restricting the survey to beneficiaries who had received transfers in the previous 30 days was important because over the six-month period of the study some beneficiaries might have left the program because of an improvement in their household's food security or because of natural attrition, and new beneficiaries might have joined the program. The 30-day window was also important to include beneficiaries who had received transfers during the same period.

Data for non-beneficiaries was obtained from household surveys, conducted by the Mozambique government's Food Security and Nutrition Secretariat in August 2011. The government conducts these household surveys in August, after which the lean season begins. The objective of the household surveys is to assess the severity and degree of food insecurity across the country and analyse the strategies of mitigation or coping with the food insecurity at the individual or institutional level (Technical Secretariat for Food Security and Nutrition 2011). Data for nonbeneficiaries was collected in August 2011, before the WFP lean season cash or food transfers started in October 2011. Only households with similar food consumption profiles and similar socio-economic criteria to a potential WFP beneficiary were selected to form the control group. Only data for participants from the same districts where both the Food Security and Nutrition Secretariat data and the WFP programmes would be rolled out in the lean season (September to March) were selected to minimize inter-district variations. The data for the current study were 
Zhou AC and Hendriks SL (2017). Does Food Assistance Improve Recipient's Dietary Diversity and Food Quality in Mozambique? Paper accepted by Agrekon, 56:3, 248-262. On line at http://www.tandfonline.com/doi/full/10.1080/03031853.2017.1360783.

drawn from the same districts in which the WFP had operated before and could implement transfers in the next lean season, but where transfer programmes had not yet been implemented. Only data for households with food consumption and socio-economic profile that would qualify them as a WFP beneficiary were included in the sample for this study.

The counterfactual data set was sourced from the most recent (August 2011, $\mathrm{n}=407$ ) National Food Security and Nutrition Secretariat survey data at the time of the study (Food Security and Nutrition Evaluation in Mozambique, 2011). This counterfactual was considered appropriate as the tools and techniques used in the National Food Security and Nutrition Evaluation surveys were the same as those that were used by the WFP Mozambique Outcome Monitoring survey (Technical Secretariat for Food Security and Nutrition 2011). The Vulnerability and Analysis Group in Mozambique's Technical Secretariat for Food Security and Nutrition (SETSAN), Mozambique Ministry of Agriculture, conducted the survey. Stratified sampling at provincial level, followed by random sampling within the districts was applied to select the sample households (SETSAN 2011).

For this study, authorization was obtained from SETSAN to use the 2011 Household Baseline Survey data and report and from WFP Mozambique to use the 2012 Outcome Monitoring Survey data. The University of Pretoria's Ethics Review Committee, where the study was conducted, approved the study protocol and gave permission to use secondary data. Respondents in both surveys were asked to consent to be interviewed and to acknowledge that they understood they were under no obligation to respond to the questions. All interviews were treated as confidential.

In both data sets, respondents were asked how many days in the previous seven they had consumed each the 17 food types listed in Table 1. The food frequency score (FFS) was calculated from their answers. The FFS was used as an indicator of dietary diversity, measuring the number of different foods consumed over the previous seven days. The mean and mode numbers were determined using SPSS (Version 20 Release 20.0) central tendency mean and mode statistics. The mean reflects the average number of days in the past week a household had consumed a food type and the mode reflects the most frequently encountered answer as to the number of days each type was consumed. 
TABLE 1 Comparative food type consumption frequency loadings

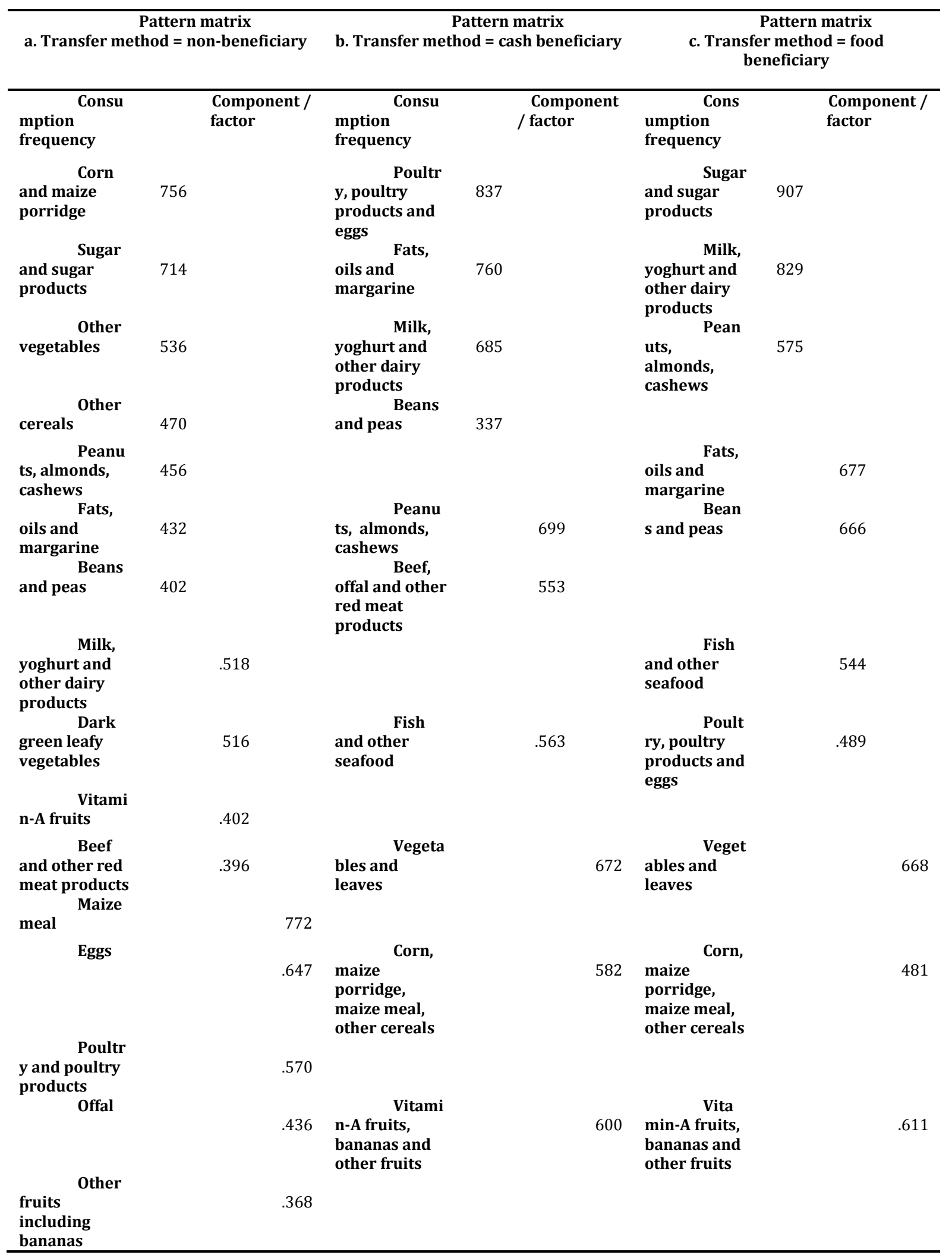




\begin{tabular}{llll}
\hline $\begin{array}{l}\text { Fish } \\
\begin{array}{l}\text { and other } \\
\text { seafood }\end{array}\end{array}$ & $\begin{array}{c}\text { Sugar } \\
\text { and sugar } \\
\text { products }\end{array}$ & $531 \begin{array}{l}\text { Beef, } \\
\text { offal and } \\
\text { other red } \\
\text { meat } \\
\text { products }\end{array}$ \\
\hline
\end{tabular}

The food frequency score (FFS) for each of the three groups: cash and food beneficiaries and non-beneficiaries, was analysed using principal component analysis (PCA) to identify patterns in the food consumption frequencies. The PCA patterns were compared to determine whether cash or food transfers affected food type consumption frequency, i.e. to compare the three groups' dietary diversity. The PCA classified the FFSs into three factors for each group (Yong and Pearce 2013). It was assumed that the factors accounted for the variance and that there was no error variance (Bartholomew, Knotts and Moustaki 2011; Field 2000; Rietveld and van Hout 1993). These factors, though latent and unobservable and thus not directly measurable, are hypothetical concepts representing variables (Cattell 1973). They make it easier to assess the frequency of consumption of the various food types and the diversity of the diet.

The food consumption score (FCS) was used as a proxy for dietary quality and measured dietary diversity and the frequency of consumption of nutrient dense foods in the diet (WFP/FAO 2008). The FFS and FCS are widely used in Demographic and Health Surveys and the WFP's food security assessments (Heady and Ecker 2013). The WFP method was used to calculate the FCS (WFP/FAO 2008). Table 1 presents the consumption frequencies for eight consolidated food types: staples (corn, maize porridge, maize meal and other cereals); pulses (beans, peas, peanuts, cashews); vegetables (vegetables, green leafy vegetables and leaves); fruit (Vitamin-A fruit, bananas and other fruit); meat and fish (red meat, red meat products, offal, poultry, poultry products, eggs, fish, seafood); milk (milk, yoghurt, dairy products); sugar (sugar and sugar products); oil (fats, margarine and oil products). The FCS, being a composite score, was calculated from the respondents' answers to questions about which food types were consumed and the frequency of consumption in the seven days prior to the survey, taking into account the nutritional ranking of the food type in a diet. The calculation is based on the combination of the frequency of consumption of the eight food types (FFS), and an established weight of the food type in the diet, based on the WFP/FAO (2008) formula below: 
Zhou AC and Hendriks SL (2017). Does Food Assistance Improve Recipient's Dietary Diversity and Food Quality in Mozambique? Paper accepted by Agrekon, 56:3, 248-262. On line at http://www.tandfonline.com/doi/full/10.1080/03031853.2017.1360783.

FCSh $=a_{\text {staple }} x_{\text {staple }}+a_{\text {pulses }} x_{\text {pulses }}+a_{\text {vegetables }} x_{\text {vegetables }}+a_{\text {fruit }} x_{\text {fruit }}+a_{\text {meat and fish }} x_{\text {meat and fish }}+a_{\text {milk }} x_{\text {milk }}+$ $a_{\text {sugar }} x_{\text {sugar }}+a_{\text {oil }} x_{\mathrm{oil}}$

FCS is the household's food consumption score, $a$ is the weight of each food type and $x$ is the household's consumption frequency score, which is the number of days on which each food type was consumed during the seven days prior to the survey. Foods consumed were weighted as follows: cereals and tubers (2), beans, peas (3), vegetables (1), fruit (1), meat, poultry and fish (4), milk (4), sugar (0.5), oil (0.5) (WFP/FAO 2008). Analysis of variance (ANOVA) was used to compare the mean FCSs of the cash and food beneficiaries and the non-beneficiaries. A post hoc test (Tukey HSD) was run on the FCS means at the 5\% level of significance. The Tukey HSD test is a multiple comparison or post hoc method, used to determine the existence of significant differences between multiple groups, in this case the FCS means (Yong and Pearce 2013).

The Monte Carlo method, used to determine the optimum number of factors to run the PCA, identified three as the optimum number of factors, where $n=863$ for 11 variables and 100 iterations (O'Connor 2000). The value of the Kaiser-Meyer-Olkin test was 0.602 for $n=247$ (cash beneficiaries), 0.656 for $n=209$ (food beneficiaries) and 0.709 for $n=407$ (non-beneficiaries). A sample is considered adequate if the value of the Kaiser-Meyer-Olkin test is greater than 0.5 (Field 2000). The PCA factor analysis mathematical model (Yong and Pearce 2013) is:

$X_{j}={ }_{a j 1} F_{1}+{ }_{a j} 2 F_{2}+{ }_{a j} F_{3}+\ldots \ldots \ldots \ldots$ ajm $F_{m}+e_{j}$

$X_{j}$ is the variable represented in the latent factors (where $j=1,2,3 \ldots . . p, P$ is the number of variables $\left(\mathrm{X}_{1}, \mathrm{X}_{2}, \mathrm{X}_{3}, \ldots \ldots \mathrm{X}_{\mathrm{p}}\right)$ and $\mathrm{m}$ is the number of latent factors $\left(\mathrm{F}_{1}, \mathrm{~F}_{2}, \mathrm{~F}_{3} \ldots \ldots \mathrm{F}_{\mathrm{m}}\right)$. The assumption in this model is that there are $m$ latent factors. The factor loadings are $a j 1, a j 2, \ldots$, ajm, which signifies that ajl is the factor loading of the $j^{\text {th }}$ variable on the first factor. The specific or unique factor is denoted by $e j$.

On the basis of this equation, food types were classified by the factor loadings on each variable (number of days each particular food type had been consumed in the previous seven days).

The factor loadings are an indication of the strength of the correlation between the factor and the variable (Kline 1994), showing how much the variable contributed to the factor. If the factor 
Zhou AC and Hendriks SL (2017). Does Food Assistance Improve Recipient's Dietary Diversity and Food Quality in Mozambique? Paper accepted by Agrekon, 56:3, 248-262. On line at http://www.tandfonline.com/doi/full/10.1080/03031853.2017.1360783.

loading is higher, this means that the variable contributed more to that factor (Harman 1976). The first factor accounts for the maximum percentage of the variance while the second and subsequent factors account for the remaining variance (Rietveld and van Hout 1993).

\section{RESULTS}

Just over half $(55 \%)$ of the survey respondents were female: $62 \%$ in the cash and food transfer group and $48 \%$ in the control group. The household size ranged from one to 17 members, with a mean of six per household and a median of four. The mean household size for cash and food beneficiaries was six members and the mode was the same. The mean household size for nonbeneficiary households was six members and the mode was five.

The mean and mode number of days the households consumed each food type are presented in Table 2. Cash and food beneficiaries as well as non-beneficiaries generally consumed staple cereals and vegetables - as expected, these were the basic food basket for all the respondents. This was confirmed by the modes. However, both cash and food beneficiaries consumed fruit, poultry, milk, red meat, oils and sugar more often than non-beneficiaries did. This was confirmed by the means. Non-beneficiaries showed higher mode values than cash and food transfer beneficiaries for nuts, cashews and fish. However, the mean for nuts, cashews and fish was lower for non-beneficiaries than for cash or food transfer beneficiaries. This was because, even though there was a large proportion of cash or food transfer beneficiaries who did not consume nuts, cashews or fish, those who did, seemed to consume nuts, cashews or fish for more days than non-beneficiaries despite the fact that the non-beneficiary survey was conducted before the lean season.

Table 1 shows three PCA pattern matrices, each matrix representing a transfer method. Factor loadings indicate the strength of the correlation between the factor (principal component) and the variable (Kline 1994), which means that if the factor loading is high, the variable contributes more to the PCA outcome (Harman 1976). Food types that clustered together on primary factors in the analyses were more likely to be consumed together frequently and to constitute a significant part of the household's diet. 
TABLE 2 Food consumption frequencies per food type

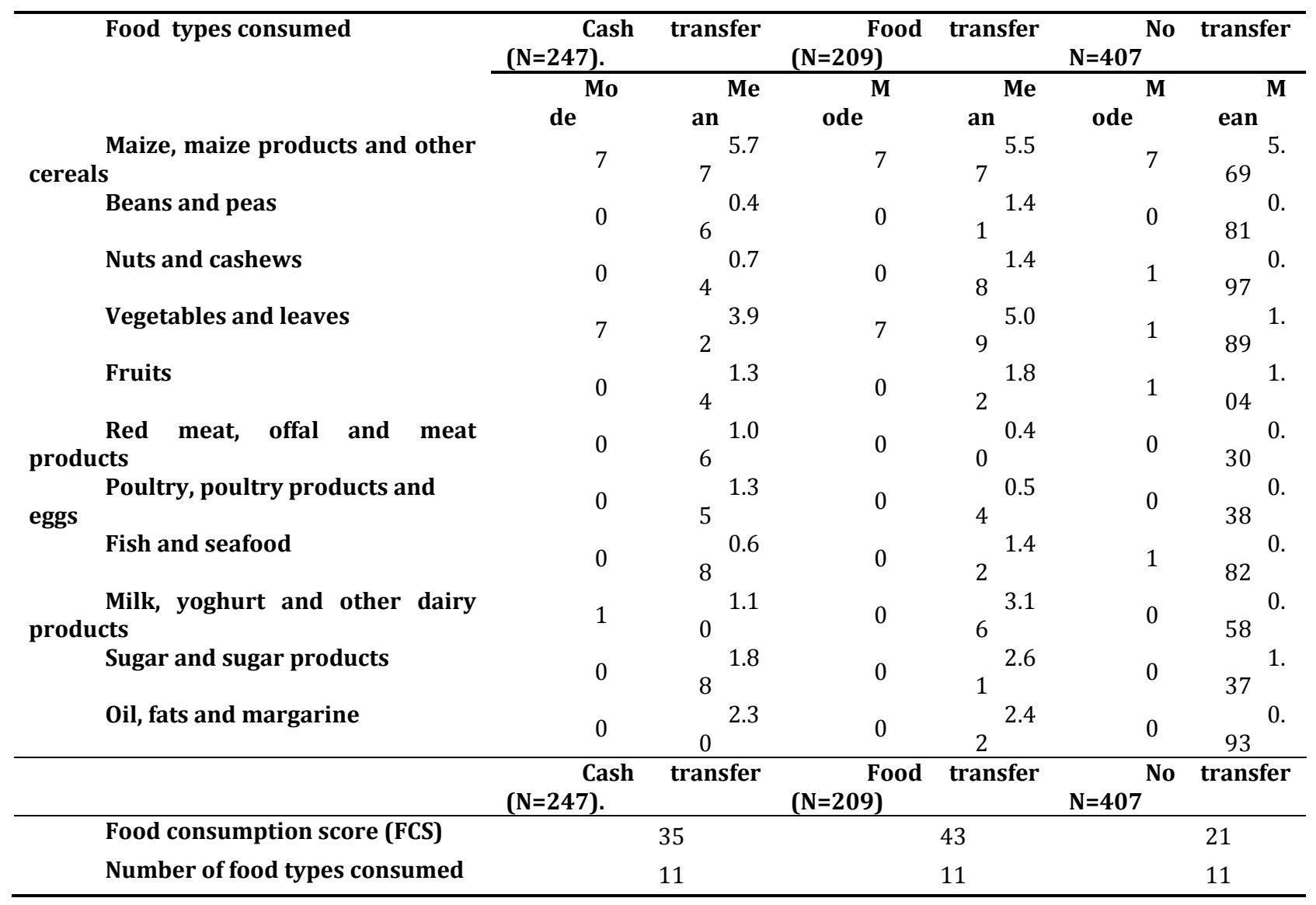

Non-beneficiaries were more likely to consume foods from the following food types: beans, corn and maize porridge, fats, oils and margarine, other cereals, peanuts and cashews, peas, sugar and sugar products, and vegetables (Table 1). They were less likely to consume dairy products, and rarely consumed fruit, poultry, poultry products, eggs, fish, other seafood, red meat and meat products. Their diets lacked diversity and were typically high in starch, vegetable based, and lacking in dairy products, meat, poultry and fruit, despite the fact that the non-beneficiary survey was conducted before the lean season.

Food transfer beneficiaries typically frequently consumed milk, yoghurt, dairy products, peanuts, cashews and sugar products together (Table 1). They consumed beans, fish, other seafood, fats, margarine, oils and peas less frequently. They were less likely to consume poultry, poultry products, eggs, red meat, meat products and fruit. Their diets were more diverse than those of 
Zhou AC and Hendriks SL (2017). Does Food Assistance Improve Recipient's Dietary Diversity and Food Quality in Mozambique? Paper accepted by Agrekon, 56:3, 248-262. On line at http://www.tandfonline.com/doi/full/10.1080/03031853.2017.1360783.

non-beneficiaries - they included nutritious foods such as fish and dairy products and, to a lesser extent, poultry and animal products.

Cash transfer beneficiaries' diets were more diverse than those of the non-beneficiaries. They were more likely to consume beans and peas, fats, margarine, oils, poultry, poultry products and eggs, milk, yoghurt and other dairy products. They consumed red meat and red meat products, peanuts and cashews, albeit infrequently. However, fruit, sugar products, fish and other seafood were not widely consumed by these beneficiaries. Their diets contained more nutrient-dense foods than the food beneficiaries' diets - they were more likely to include milk, dairy products, poultry, eggs, poultry products, and meat and meat products. Red meat was likely to be included more frequently in their diets than in those of the food transfer beneficiaries, who did not commonly consume red meat.

The food consumption score (FCS) provided an indication of diet quality that took into account the food frequency score (FFS) as well as the weights of the consumed foods according to nutritional importance. As per the WFP/FAO (2008) classification, an FCS below 21 indicates 'poor food consumption'; between 21.5 and 35 indicates 'borderline', i.e. not poor but not adequate either; and above 35 indicates 'adequate food consumption', sufficient to meet household dietary needs. The FCSs in this study confirmed the findings of the FFSs, showing that both cash and food transfers improved the diets of beneficiary households. The mean FCSs for cash transfer beneficiaries, food transfer beneficiaries and non-beneficiaries were 35, 43 and 27 respectively (Table 3). On average, the non-beneficiaries' diets were found to be 'borderline or inadequate', while those of the cash and food transfer beneficiaries were 'adequate'. The scores for the three groups were significantly different (Tables 4 and 5), indicating distinct consumption patterns for the three groups.

The fact that the cash beneficiaries' FCS was lower than the food transfer beneficiaries' FCS indicated that the cash beneficiaries' diets were less diverse than those of the food transfer beneficiaries even though the cash transfer beneficiaries' diets contained more nutrient-dense foods than those of the food beneficiaries. It should be remembered that the FCS is a composite of the frequency of consumption of diverse food groups and the nutritive importance of the foods consumed. 
Zhou AC and Hendriks SL (2017). Does Food Assistance Improve Recipient's Dietary Diversity and Food Quality in Mozambique? Paper accepted by Agrekon, 56:3, 248-262. On line at http://www.tandfonline.com/doi/full/10.1080/03031853.2017.1360783.

TABLE 3 Food consumption score (FCS) means

\begin{tabular}{|c|c|c|c|c|c|c|c|c|c|}
\hline & & & ean & $\begin{array}{l}\text { St } \\
\text { d. dev. }\end{array}$ & $\begin{array}{l}\text { S } \\
\text { td. } \\
\text { error }\end{array}$ & \multicolumn{2}{|c|}{$\begin{array}{l}95 \% \text { confidence } \\
\text { interval for mean }\end{array}$} & $\begin{array}{r}\text { Mi } \\
\text { nimum }\end{array}$ & $\begin{array}{r}\text { Ma } \\
\text { ximum }\end{array}$ \\
\hline & 1 & & 3 & 1 & & 33.753 & 36.7 & 2. & 72. \\
\hline ash & & 47 & 5.255 & 1.988 & 763 & & 57 & 00 & 50 \\
\hline & 1 & & 4 & 1 & 1 & 40.848 & 45.0 & 10 & 91. \\
\hline ood & & 09 & 2.966 & 5.529 & .074 & & 83 & .50 & 65 \\
\hline & 1 & & 2 & 5. & & 26.602 & 27.6 & 12 & 46. \\
\hline one & & 07 & 7.134 & 455 & 270 & & 66 & .00 & 00 \\
\hline & $r$ & & 3 & 1 & & 32.461 & 34.1 & 2. & 91. \\
\hline otal & & 63 & 3.293 & 2.446 & 424 & & 24 & 00 & 65 \\
\hline
\end{tabular}

TABLE 4 ANOVA food consumption score means (FCS)

\begin{tabular}{cccccc}
\hline & $\begin{array}{c}\text { Sum of } \\
\text { squares }\end{array}$ & df & $\begin{array}{c}\text { Mean } \\
\text { square }\end{array}$ & F & Sig. \\
\hline \multicolumn{1}{c}{ Between } & 35943.854 & 2 & 17971.927 & 158. & .000 \\
groups & & & & 370 & \\
Within groups & 97593.065 & 860 & 113.480 & & \\
Total & 133536.920 & 862 & & \\
\hline
\end{tabular}


Zhou AC and Hendriks SL (2017). Does Food Assistance Improve Recipient's Dietary Diversity and Food Quality in Mozambique? Paper accepted by Agrekon, 56:3, 248-262. On line at http://www.tandfonline.com/doi/full/10.1080/03031853.2017.1360783.

TABLE 5 Post hoc test for food consumption score (FCS) means

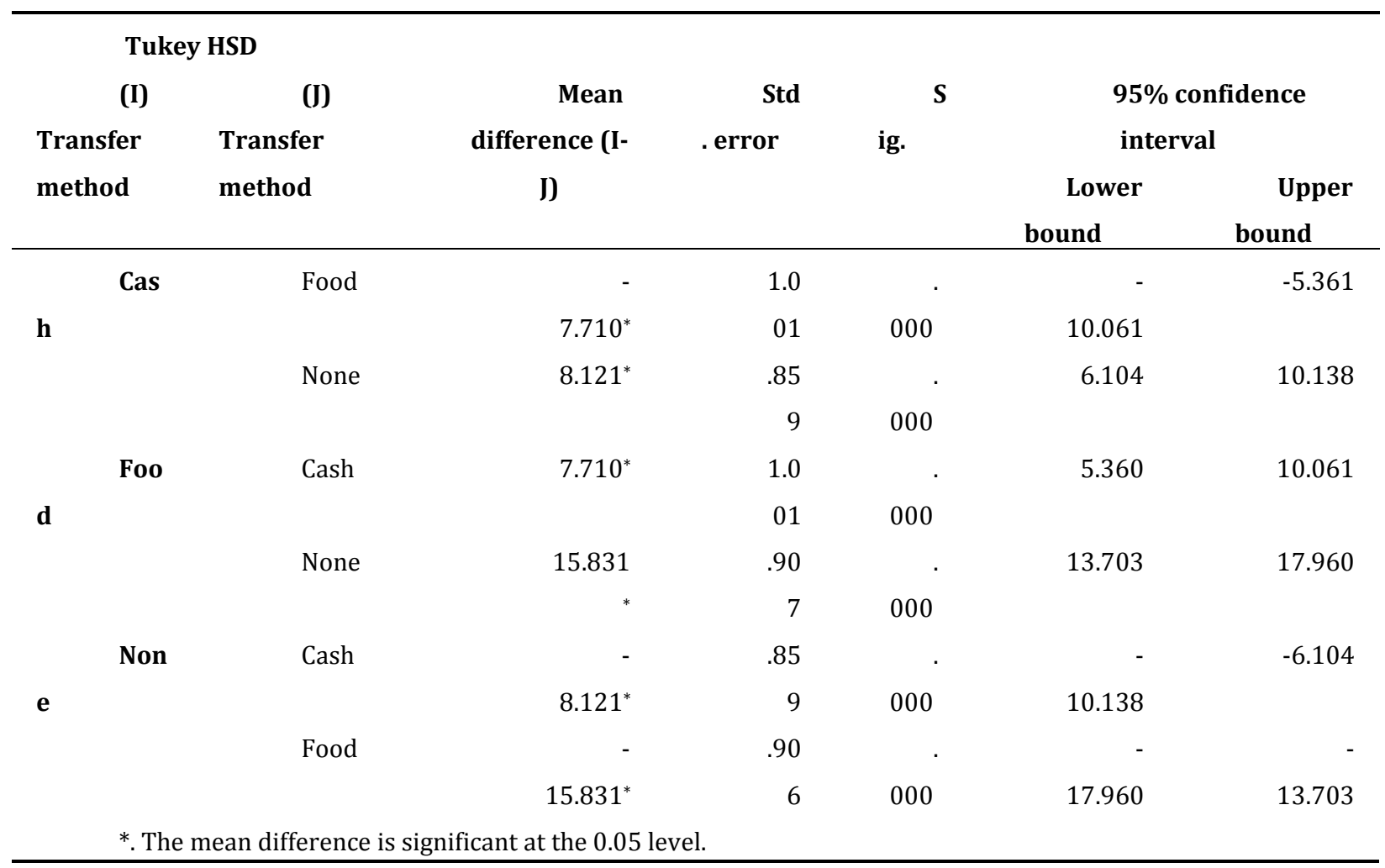

\section{CONCLUSIONS AND RECOMMENDATIONS}

This paper investigated the influence of WFP's cash and food transfers on the diversity and quality of diets among chronically food insecure households in Mozambique and the implications of this for the design of WFP's systemic food assistance intentions. Distinct consumption patterns were found for these two groups and a counterfactual group, with important implications for food assistance. Food assistance has the potential to turn need into market demand (World Bank, 2016). However, realising this demand requires purchasing power on behalf of the consumers as well as the existence of operational markets for supplying commodities. Both are often lacking in the contexts in which WFP operates. However, understanding the potential for food assistance to generate demand for nutritious foods is a starting point. The findings of this study show that food assistance has the potential to turn need into demand. 
Zhou AC and Hendriks SL (2017). Does Food Assistance Improve Recipient's Dietary Diversity and Food Quality in Mozambique? Paper accepted by Agrekon, 56:3, 248-262. On line at http://www.tandfonline.com/doi/full/10.1080/03031853.2017.1360783.

Cash and food transfers improved dietary diversity and quality, but in different ways. Food consumption scores (FCSs) showed that the diets of both cash and food transfer beneficiaries were nutritionally adequate. However, food transfers - although providing only basic staple foods - led to more improved dietary diversity than cash transfers. Food transfer beneficiaries received a basic food parcel of 45 kilograms of cereal, nine kilograms of cowpeas and threequarters of a litre of oil per month. This seemed to enable them to supplement their diets with milk, yoghurt and other dairy products, and fish and other seafood, generating demand for these nutritious foods. The non-beneficiaries' diets lacked these foods.

Although cash transfer beneficiaries had slightly lower dietary diversity than the food transfer beneficiaries, cash transfers led to more frequent consumption (and demand) for nutrient-dense foods such as milk, yoghurt and other dairy products, poultry, eggs and poultry products, red meat and meat products. Even though cash beneficiaries had access to, and were more readily able to purchase highly nutritious foods, they did not seem to consume as wide a range of food types with the same frequency as the food transfer beneficiaries (as indicated by the cash beneficiaries' lower FCS). This may have been attributed to the small sum of cash they received that was not sufficient to purchase diverse foods or many have been diverted to non-food expenditure.

Given these findings, in some contexts, it appears that a food component does improve diet and should be considered with food assistance programmes are being designed. Direct food provision leads to improvement in dietary diversity, while cash enables beneficiaries to purchase more nutritious foods, improving diet quality. Careful assessment of which foods are typically available in beneficiary households is recommended to avoid providing foods already available (such as starchy staples), but rather supplementing these with foods of higher nutritive value that are not regularly consumed. Households could use the cash portion to buy foods of higher nutritive value such as dairy products, eggs, fish, meat, poultry, and so on. Both cash and food transfers have potential to generate demand for a variety of nutritious foods in the communities investigated through this study. Providing adequate rations of basic food and a cash portion could improve both dietary diversity and quality and stimulate demand for nutritious foods by addressing both income (purchasing power) constraints as well as stimulating demand for these 
Zhou AC and Hendriks SL (2017). Does Food Assistance Improve Recipient's Dietary Diversity and Food Quality in Mozambique? Paper accepted by Agrekon, 56:3, 248-262. On line at http://www.tandfonline.com/doi/full/10.1080/03031853.2017.1360783.

foods. This demand could have a pull factor in terms of local food systems, stimulating demand not only for food but also food system services - both upstream and downstream.

However, context analysis is necessary. As these interventions are typically implemented in areas where food systems are broken or weak and localised, cash injections may result in price spikes, eroding purchasing power (World Bank 2016). Private traders may lack incentives to supply commodities. A basic level of market functioning is, therefore, a prerequisite for the effective provision of cash transfers and to enable local economic multipliers (World Bank 2016).

This study contributes to the evidence gap on how different transfer modalities contribute to improving the diets of food assistance beneficiaries. The findings contribute to understanding how WFP's current programmes affect household dietary diversity and quality. Such insight is essential to inform the design of future programmes as part of WFP's Strategic Plan for 2017 2021, but contributes more broadly to understanding the systemic food system influences food assistance programmes can have in development contexts.

Similar studies in other areas of Mozambique are recommended where the WFP has programs, to investigate whether the same responses to food assistance exist and whether local markets indeed have the ability to respond to increased demand for nutritious foods. Systematic review and assessment in other countries is also recommended to test the potential of systemic food assistance to improve nutrition among beneficiaries in development contexts, while simultaneously enhancing the performance of food systems to leverage broad-based and inclusive development.

Improved food availability through cash and food transfers may not be enough to guarantee dietary improvements at the individual level because household dynamics and preferences affect the way the transfers are used. Therefore, further studies are recommended to relate individual dietary diversity and quality to household dietary diversity and quality to determine how household dynamics influence individual access to available food. 
Zhou AC and Hendriks SL (2017). Does Food Assistance Improve Recipient's Dietary Diversity and Food Quality in Mozambique? Paper accepted by Agrekon, 56:3, 248-262. On line at http://www.tandfonline.com/doi/full/10.1080/03031853.2017.1360783.

\section{REFERENCES}

Andersson, C., A. Mekonnen and J. Stage. 2011. Impacts of the productive safety net program in Ethiopia on livestock and tree holdings of rural households. Journal of Development Economics 94: 119-126.

Arnold, C., T. Conway and M. Greenslade. 2011. DFID cash transfers literature review. London: DFID (Department for International Development) Policy Division.

Audsley, B., R. Halme and N. Balzer. 2010. Comparing cash and food transfers: A cost-benefit analysis from rural Malawi. In Revolution: From food aid to food assistance. Innovations in overcoming hunger, ed. S.W. Omamo, U. Gentilini and S. Sandström, 89-102. Rome: World Food Programme.

Barrientos, A. 2010. Social protection and poverty. Social Policy and Development Paper 42. Geneva: United Nations Research Institute for Social Development.

Bartholomew, D., M. Knotts and I. Moustaki. 2011. Latent variable models and factor analysis: A unified approach (3rd edition). West Sussex: John Wiley and Sons.

Caldes, N., D. Coady and J. Maluccio. 2006. The cost of poverty alleviation transfer programs: A comparative analysis of three programs in Latin America. World Development 34 (5): 818837.

Cattell, R.B. 1973. Factor analysis. Westport: Greenwood Press.

Coady, P.D. 2004. Designing and evaluating social safety nets: Theory, evidence and policy conclusions. Food Consumption and Nutrition Division Discussion Paper No. 172. Washington, DC: International Food Policy Research Institute.

Currie, J. and F. Gahvari. 2008. Transfers in cash and in-kind: Theory meets the data. Journal of Economic Literature 46(2): 333-383.

de Brauw, A. and J. Hoddinott. 2011. Must conditional cash transfer programs be conditioned to be effective? The impact of conditioning transfers on school enrollment in Mexico. Journal of Development Economics 96(2): 359-370.

Devereux, S. 2006. Cash transfers and social protection. Paper presented at regional workshop on cash transfer activities in southern Africa, co-hosted by the Southern African Regional Poverty Network (SARPN), Regional Hunger and Vulnerability Program (RHVP) and Oxfam Great Britain, Johannesburg, 9-10 October. 
Devereux, S. 2010. Building social protection systems in southern Africa. Paper prepared in the framework of the European Report on Development. http://erd.eui.eu/media/BackgroundPapers/Devereaux\%20\%20BUILDING\%20SOCIAL\%20PROTECTION\%20SYSTEMS.pdf (accessed 18 April 2015).

Drèze, J. 1990. Famine prevention in India. In The political economy of hunger, ed. J. Drèze, A. Sen, and A. Hussain, 13-122. Oxford: Clarendon Press.

FAO (Food and Agriculture Organization). 2002. The state of food insecurity in the world. Rome: FAO.

Farrington, J. and R Slater. 2006. Introduction: Cash transfers: Panacea for poverty reduction or money down the drain? Development Policy Review 24 (5): 499-511.

Field, A. 2000. Discovering statistics using SPSS for Windows. London: Sage.

Fiszbein, A., N. Schady, F.H.G. Ferreira, M. Grosh, N. Kelleher, P. Olinto and E. Skoufias. 2009. Conditional cash transfers: Reducing present and future poverty. A World Bank Policy Report. Washington, DC: World Bank.

Gentilini, U. 2007. Cash and food transfers: A primer. World Food Programme Occasional Paper No.18. Rome: World Food Programme.

Gentilini, U. 2014. Our daily bread: What is the evidence on comparing cash versus food transfers? Social Protection and Labour Discussion Paper No. 1420. Washington, DC: World Bank.

Gilligan, D.O., J. Hoddinott and A.S. Taffesse. 2008. The impact of Ethiopia's productive safety net program and its linkages. IFPRI Discussion Paper 00839. Washington, DC: International Food Policy Research Institute.

Gough, I. and G. Wood. 2004. Introduction: Insecurity and welfare regimes in Asia, Africa and Latin America. In Insecurity and welfare regimes in Asia, Africa and Latin America: Social policy in development contexts, ed. I. Gough, and G. Wood, 1-11. Cambridge: Cambridge University Press.

Grosh, M., C. Del Nino, E. Tesliuc and A. Ouerghi. 2008. The design and implementation of effective safety nets for protection and promotion. Washington, DC: World Bank.

Harman, H.H. 1976. Modern factor analysis (3rd edition revised). Chicago: University of Chicago Press. 
Zhou AC and Hendriks SL (2017). Does Food Assistance Improve Recipient's Dietary Diversity and Food Quality in Mozambique? Paper accepted by Agrekon, 56:3, 248-262. On line at http://www.tandfonline.com/doi/full/10.1080/03031853.2017.1360783.

Harvey, P. 2007. Cash-based responses in emergencies. Humanitarian Policy Group report 24. London: Overseas Development Institute.

Harvey, P. and S. Bailey. 2011. Good practice review: Cash transfer programming in emergencies. Good Practice Reviews No. 11. Humanitarian Practice Network. London: Overseas Development Institute.

Heady, D. and O. Ecker. 2013. Rethinking the measurement of food security: From first principle to best practice. Food Security 5: 327-343.

Herrmann, H. 2009. An introduction and review of cash transfer experiences and their feasibility as a food security tool for World Food Programme in Bolivia. Consultancy report. Swiss Agency for Development and Cooperation and the World Food Programme, Bolivia.

Hidrobo, M., Hoddinott, J., Peterman, A., Margolies, A. and Moreira, V. 2014. Cash, food, or vouchers? Evidence from a randomized experiment in northern Ecuador. Journal of Development Economics 107: 144-156.

HLPE (High Level Panel of Experts of the United Nations Committee on World Food Security). 2012. Social protection for food security. Report number 4. Rome: HLPE.

HLPE (High Level Panel of Experts of the United Nations Committee on World Food Security). 2014. Food losses and waste in the context of sustainable food systems. A report by the High Level Panel of Experts on Food Security and Nutrition of the Committee on World Food Security, Rome. URL: http://www.fao.org/3/a-i3901e.pdf.

Hoddinott, J. and E. Skoufias. 2004. The impact of PROGRESA (Programa de Educación, Salud, y Alimenación) on food consumption. Economic Development and Cultural Change 53 (1): 37-61.

Hoddinott, J. and D. Wiesmann, D. 2010. The impact of conditional cash transfer programs on food consumption. In Conditional cash transfers in Latin America, ed. M. Adato, and J. Hoddinott, 258-283. Baltimore: Johns Hopkins University Press.

Hoddinott, J., D. Gilligan, M. Hidrobo, A. Margolies, S. Roy, S. Sandström, B. Schwab and J. Upton. 2013. Enhancing WFP's capacity and experience to design, implement, monitor, 
and evaluate vouchers and cash transfer programs: Study summary. Washington, DC: International Food Policy Research Institute.

Jahan, S. 2015. Human Development Report. Work for Human Development. United Nations

Development Programme, New York. URL:

http://hdr.undp.org/sites/default/files/2015_human_development_report_1.pdf

Jones, W.P., M. Vavra, A. von Lampe, L. Fournier, C. Fulponi, P. Giner, et al. 2010. Organisation for Economic Cooperation and Development (OECD) and the Food and Agriculture Organization of the United Nations (FAO). Agricultural Outlook 2010-2019. 6th edition. Rome: FAO.

Kline, P. 1994. An easy guide to factor analysis. New York: Routledge.

Malik, K. 2013. The Rise of the South: Human Progress in a Diverse World. United Nations Development Programme, Human Development Report. New York. URL: http://hdr.undp.org/sites/default/files/reports/14/hdr2013_en_complete.pdf

Matin, I., M. Sulaiman and M. Rabbani. 2008. Crafting a graduation pathway for the ultra poor: Lessons and evidence from a BRAC (Bangladesh Rural Advancement Committee) program. CPRC (Chronic Poverty Research Centre) Working Paper 109. Manchester: CPRC.

Maunder, N., Dillon, N., Smith, G., Truelove, S. and De Bauw, V. 2016. Evaluation of the use of different transfer modalities in European Commission (ECHO) humanitarian aid actions 2011-2014. Evaluation report commissioned by the Evaluation Sector of the Directorate General Humanitarian Aid and Civil Protection - ECHO (European Commission). Louvain-la-Neuve (Belgium): ECHO.

Maxwell, D.G., E.C. Lentz and Barrett, C. 2007. A market analysis and decision tree tool for response analysis: Cash, local purchase and/or imported food aid? Background paper. Atlanta: Food Resources Coordination Team, Cooperation for Assistance and Relief Everywhere (CARE). 
Zhou AC and Hendriks SL (2017). Does Food Assistance Improve Recipient's Dietary Diversity and Food Quality in Mozambique? Paper accepted by Agrekon, 56:3, 248-262. On line at http://www.tandfonline.com/doi/full/10.1080/03031853.2017.1360783.

Molyneux, M. 2007. Two cheers for conditional cash transfers. International Development Studies Bulletin 38 (3): 69-74.

O'Connor, B. 2000. SPAA and SAS programs for determining the number of components using parallel analysis and Velicer's MAP test. Behaviour Research Methods, Instruments and Computers 32 (3): 396-402.

Oduro, A.D. 2010. Formal and informal social protection in sub-Saharan Africa. Background paper to European Report on Development. Paper presented at workshop "Promoting Resilience through Social Protection in sub-Saharan Africa" organized by the European Report on Development, Dakar, 28-30 June.

Omamo, S.W., U. Gentilini and S. Sandstrom. 2010. Innovations in food assistance: Issues, lessons and implications. In Revolution: From food aid to food assistance. Innovations in overcoming hunger, ed. S.W. Omamo, U. Gentilini and S. Sandström, 1-18. Rome: World Food Programme.

Overseas Development Institute. 2015. Doing cash differently: How cash transfers can transform humanitarian aid. Report for the High Level Panel on Humanitarian Cash Transfers. Londaon: ODI.

Rabbani, M., V.A. Prakash and M. Sulaiman. 2006. Impact assessment of CFPR/TUP (Challenging the Frontiers of Poverty Reduction/ Targeting the Ultra Poor): A descriptive analysis based on 2002-2005 panel data. CFPR/TUP Working Paper 12. Dhaka and Ottawa: BRAC (Bangladesh Rural Advancement Committee) Research and Evaluation Division and the Aga Khan Foundation.

Rietveld, T. and R. van Hout. 1993. Statistical techniques for the study of language and language behaviour. Berlin and New York: Mouton de Gruyter.

Ruel, T.M. 2002. Is dietary diversity an indicator of food security or dietary quality? A review of measurement issues and research needs. Food Consumption and Nutrition Division discussion paper no. 140. Washington, DC: International Food Policy Research Institute.

SETSAN (Technical Secretariat for Food Security and Nutrition). 2011. Food security and nutrition evaluation in Mozambique. Maputo: Ministry of Agriculture.

Stevenson, D. and U. Gentilini. 2008. Vouchers and cash transfers as food aid assistance instruments: Opportunities and challenges. Paper presented at World Food Programme Executive Board Second Regular Session, Rome, 27-30 October. 
Zhou AC and Hendriks SL (2017). Does Food Assistance Improve Recipient's Dietary Diversity and Food Quality in Mozambique? Paper accepted by Agrekon, 56:3, 248-262. On line at http://www.tandfonline.com/doi/full/10.1080/03031853.2017.1360783.

UN (United Nations) General Assembly, 2014, Report of the Open Working Group of the General Assembly on Sustainable Development Goals. Report issued as document A/68/970, available at http://undocs.org/A/68/970. Washington, DC: United Nations. URL:

https://sustainabledevelopment.un.org/content/documents/1579SDGs\%20Proposal.pdf. Accessed 19 May 2017.

USAID. (United States Agency for International Aid) 2007. Mozambique food programming framework FY 2008-2012. United States Agency for International Aid. Maputo.

Victora, C.G., L. Adair, C. Fall, P.C. Hallal, R. Martorell, L. Richter and H.S. Sachdev. 2008. Maternal and child under nutrition: Consequences for adult health and human capital. The Lancet 371: 340-357.

Wagstaff, A. and N. Watanabe. 2000. Socio economic inequalities in child malnutrition in the developing world. Policy Research Working Paper 2434. Washington, DC: World Bank.

WFP (World Food Programme). 2017. Systemic Food Assistance. Paper prepared as an interim strategic and operational guidance for WFP engagement and investment in food systems. Food Systems Strategy, Policy and Support Service. Rome: Word Food Program

WFP (World Food Programme). 2016. WFP Strategic Plan (2017-2021). WFP Executive Board, Second Regular Session, Rome 14 - 18 November 2016, Agenda Item 4, WFP/EB.2/2016/4-A/1/Rev.2. http://documents.wfp.org/stellent/groups/public/documents/eb/wfp286743.pdf?_ga=2.1725 69059.1719692935.1495187674-81988171.1457343863. Accessed 19 May 2017.

WFP (World Food Programme). 2011. Mozambique Country Program 2012-2015. Maputo: World Food Programme. 
WFP/FAO (World Food Programme/ Food and Agriculture Organization), 2008. Interagency workshop report WFP/FAO. Measures of food consumption: Harmonizing methodologies. Rome: World Food Programme.

World Bank. 2015. Cash transfers in humanitarian contexts. Strategic note prepared for the Principals of the Inter-Agency Standing Committee on Humanitarian Assistance. Washington DC: The World Group.

Yong, A.G., and S. Pearce. 2013. A beginner's guide to factor analysis: Focusing on exploratory factor analysis. Tutorials in Quantitative Methods for Psychology 9 (2): 79-94. 